\title{
Food and beverage industry competitiveness and halal logistics: perspective from small and medium enterprises in Malaysia
}

\author{
Maizaitulaidawati Md Husin ${ }^{1,2, *}$, Suzilawati Kamarudin², \\ Adriana Mohd Rizal ${ }^{1}$ \\ ${ }^{1}$ Azman Hashim International Business School, Universiti Teknologi Malaysia, \\ Kuala Lumpur, Malaysia \\ ${ }^{2}$ University of Business and Technology, Jeddah, Saudi Arabia \\ ${ }^{*}$ Corresponding author: maizaitulaidawati@gmail.com
}

\begin{abstract}
Purpose: This paper investigates the competitiveness of the food and beverages (F\&B) industry in Malaysia and examines the Small and Medium Enterprises' (SMEs) demand and key perceptions towards challenges in halal logistics.

Methodology: This paper adopted SWOT analysis to understand the internal (strengths, weaknesses) and external (opportunities and threats) competitiveness of the industry. Interview sessions were conducted with 10 SMEs' owners in the food industry from December 2020 until February 2021.

Findings: The SWOT analysis identified several strengths (e.g. workforce diversity, well-established equipment, and facilities), weaknesses (e.g. a limited number of skilled workforce, lack of industrial collaboration, lack of distribution channel), opportunities (e.g. increasing food demand, advanced technology, supportive government initiatives, favorable business environment) and threats (e.g. high cost, new and changing regulation). The SMEs' perception towards key challenges in halal logistics was also identified.
\end{abstract}

Research limitations/implications: This paper provides an understanding of the competitiveness of the F\&B industry, sheds light on the key challenges faced by SME owners in halal logistics, and offers strategies to solve the issues. This study, however, is limited to Malaysia's experience.

Practical implications: This paper will contribute to future studies in the similar field and offers a guide for Halal logistics players, including practitioners and policymakers, to understand their business environment better. The identification of SMEs' SWOT will be helpful for the businesses to move forward.

Originality: The value of this paper lies in the knowledge of SMEs, especially in the $\mathrm{F} \& \mathrm{~B}$ industry.

Keyword: Small and medium-sized enterprises (SMEs), competitiveness, halal, logistic, SWOT, food and beverages.

Cite this article:

Husin, M. A., Kamarudin, S., \& Rizal, A.M (2021). Food and beverage industry competitiveness and halal logistics: Perspective from small and medium enterprises in Malaysia. Asian Journal of Islamic Management, 3 (1), 1-10. https://doi.org/10.1108/AJIM.vol3.iss1.art1
Article history

Received, 20 April 2021

Revised 1, 1 May 2021

Revised 2, 3 May 2021

Accepted, 28 May 2021

\section{Introduction}

Logistics plays a crucial role in protecting and preserving the integrity of halal food. The logistics of halal foods cover the shariah-compliant transportation, storage, warehousing, and handling process along the supply chain process until it reaches its final destination. The rising halal product 
demands of Muslim consumers, mainly food and beverages (F\&B), have increased the potential for halal food logistics services. Beyond the food sector, the halal industry has evolved and expanded to other industries such as cosmetic (Divianjella et al., 2020; Wajdi et al., 2020), travel and tourism (Rahman et al., 2020; Wardi et al., 2018), healthcare and pharmaceuticals (Ramli et al., 2018), as well as financial service and investment (Billah, 2019; Abdullah \& Oseni, 2017).

Halal is derived from the Arabic word, which means lawful. With regards to food, the Islamic law (shariah) requires the food to fulfill several conditions such as slaughtered in the name of Allah, does not contain any haram parts, ingredients, or products of prohibited animals (Matulidi et al., 2016). Halal is not just about the food, but it also affects preparing the food whereby the contamination with non-Halal ingredients in preparing, processing, or manufacturing the food should be avoided. In addition to that, the use of tools or equipment of halal and non-halal equipment is prohibited (Karia, 2019). Thus, to ensure the halal process of the supply chain, the manufacturing, preparation, packaging and labeling, storage, display, and distribution of the food must be totally separated between halal and haram products.

It was estimated that Muslims around the world consumed about US $\$ 2.3$ trillion of halal goods, ranging from food to cosmetics, in 2017, where US $\$ 1.3$ trillion was spent on food (Azhar, 2019). In 2018, the global halal food market was valued at US $\$ 1140$ Million and was expected to reach US $\$ 1590$ Million by the end of 2025, growing at a CAGR of 4.3 percent (More, 2021). According to Azhar, (2019), Malaysia's export value of halal-certified products was RM40 billion in 2018, and F\&B comprised half of the value. Muslim population worldwide, GDP growth of Muslim countries, emerging halal markets, Muslim lifestyle offerings, and the growth of the halal ecosystem are among many factors that affect the demand for halal-certified products (Azam \& Abdullah, 2020). The fact that the non-Muslims are also becoming more interested in consuming halal products, as it associates with quality, cleanliness, and safety, enhance the importance of producing more halal products (Battour et al., 2018; Rezai et al., 2012; Wibowo \& Ahmad, 2016). The increasing demand for halal-certified products offers a brilliant opportunity for the Malaysian economy. However, the current condition suggests a limited need for halal food logistics due to some challenges and issues throughout the halal supply chain (Mahidin et al., 2017). Among the challenges and issues are maintaining halal performance during the transportation process (Tan et al., 2012). For example, Suzana et al. (2011) addressed that achieving halal supply chain compliance is a challenge because logistics service providers (LSP) can only be guaranteed when the products are in their custody, not during the transportation process.

This paper, thus, aims to examine the internal (strengths, weaknesses) and external (opportunities and threats) competitiveness level of SMEs in the F\&B industry. This paper also identifies the demand for halal food logistics and the key challenges SMEs face in halal food logistics. Three research objectives were developed.

Objective 1. To identify the strengths and weaknesses of SMEs in the F\&B industry

Objective 2. To examine the opportunities and threats facing SMEs in the F\&B industry

Objective 3. To investigates the demand and key challenges faced by SMEs with regards to halal food logistics

The second section briefly describes the competitiveness of the F\&B industry, followed by a specific discussion on Malaysia's F\&B industry. Next, a review on the halal industry and halal logistics, specifically in Malaysia, is deliberated. The research method is discussed in the third section, followed by a presentation of the results' findings. The discussion and conclusion section is presented at the end of the paper.

\section{Literature Review and Hypotheses Development}

\section{The Competitiveness of Food and Beverage Industry}

For a country, competitiveness is defined as the set of institutions, policies, and factors that determine productivity. In the Agri-Food sector, competitiveness has been described as the sustained ability to profitably gain and maintain market share (Notta \& Vlachei, 2010). 
Competitiveness is always associated with technology, innovation, incremental improvements, and continuous strategies to stay ahead of competitors. Many studies are measuring the competitiveness of the F\&B industry around the world. For example, in the European Union, Fischer \& Schornberg (2007) assess the competitiveness of the meat processing and beverage manufacturing sectors from different dimensions such as economic, profitability, productivity, and growth. Commission (2006) also measures the competitiveness of the European F\&B industry, but he looks from an economic and legal perspective. In Asia, Toaha et al. (2019) looks at the competitive sustainability of F\&B SMEs in South Sulawesi. Jumady et al. (2016), on the other hand, evaluate the effects of integrative supply chain management and competitiveness of the F\&B manufacturing companies in Makassar. In sum, competitiveness can be viewed from different perspectives, from a larger scale, such as economic, to a small scale like company and its operation.

For an F\&B business to stay ahead in the industry, a severe look at several attributes, such as digitalization and automation, are needed. Digitalization has been identified as one of the keys to innovation, which can affect consumer intimacy. A business that can leverage digitalization may change provide a new source of revenue and value-producing opportunities by using the widely available data gathered from public sources, market research, and social media. Further to that, by leveraging on automation, an F\&B business, either SMEs or big, well-established companies, can be optimized against constraints to save time, avoid disruptions, and increase information clarity and consistency across the businesses. Thus, it was believed that a digital and automated F\&B company has a distinct advantage over its competition.

\section{Malaysia's Food and Beverage Industry}

The food and beverage industry plays and contributes a significant amount to the Malaysian economy. In 2018, the Malaysia F\&B industry was recorded growing annually at $7.6 \%$ and valued at around $€ 22.12$ billion (Flanders Investment \& Trade, 2020). The F\&B industry in Malaysia is diverse, with a wide range of food for Asian taste, dietary preferences, and many western recipes. There are various outlets in the $F \& B$ industry ranging from full-service restaurants, street stalls/kiosks, fast-food cafés/bars, and self-service cafeterias. This industry is predominantly dominated by SMEs (Italian Trade Agency, 2017).

The market for food and beverage products in Malaysia is not limited by its grown agricultural product. Malaysia is a growing food processing industry, estimated to account for over 1/10th of Malaysia's manufacturing output (European Commission, 2018). According to the Malaysian Investment Development Authority (2019), processed food has been exported to more than 200 countries and contributed about RM21.76 billion. Quoquab et al. (2019) mentioned that demand for fast food demand among Malaysian, either for American franchises foods such as KFC, Pizza Hut, and McD or the local fast-food franchises such as Secret Recipe, Hot and Roll, and Manhattan Fish Market, are gaining popularity. Interestingly, demand for organic, natural, and fresh foods is also increasing (LNG, 2019). For example, Hassan et al. (2015) and See \& Shaheen (2012) mentioned that the demand for organic food consumption in Malaysia had increased significantly due to several reasons, including affordability of the food as well as acceptability and awareness of the consumers. These constantly shifting trends among the consumers is the primary factor affecting the growth of Malaysia's F\&B industries.

The increasing food delivery apps such as Grab Food, Food Panda, Delivereat, and Dahmakan contribute to the growing demand for food and enhance consumers' availability, contributing to extensive growth in the $\mathrm{F} \& \mathrm{~B}$ industry. It also translated to the increasing number of restaurants and fast-food chains in the country.

\section{Halal Industry in Malaysia}

Malaysia is known as the leading global halal hub. Each year, Malaysia took the initiative to host two of the most significant events in the halal industry, namely the World Halal Forum (WHF) and 
the Malaysia International Halal Showcase (MIHAS). Both events were organized annually and bring opportunities across the global Halal markets where companies involve in halal products and services are given opportunities to showcase their products and services. Many sectors such as $\mathrm{F} \& \mathrm{~B}$, tourism, pharmaceutical, cosmetics, logistics, Islamic finance, e-commerce, food technology, education, modest fashion, and franchise participated in the events. These events also play a pivotal role in building the country's reputation as the global reference and trade center for the new mainstream halal industry.

Regarding halal for F\&B, the Department of Islamic Development Malaysia, popularly known as JAKIM, a federal government agency in Malaysia, is responsible for issuing Halal certification for F\&B manufacturers. Malaysia Halal Certification offers two categories of applications which are domestic and international halal certification, ranging for food product/beverage/food supplement, food premise and hotel, consumer goods, cosmetics and personal care, pharmaceutical products, slaughterhouse, logistics which also includes warehousing, transport, and retailing, and original equipment manufacturer (Sirajuddin et al., 2019).

\section{Halal Logistics}

Halal logistics covers the whole supply chain process, conformity to a halal standard. The process covers several processes, such as the production and processing of the product, packaging, storage and warehousing process, transportation, inventory, scheduling and distribution, retailing, and delivery of the product to the consumer. In Malaysia, several ports such as Penang Port, Port Klang, and the Port Klang Free Zone have been certified as shariah-compliant ports and been promoted to be involved in producing halal products for export (Mahidin et al., 2016).

Many studies have been conducted in understanding and examining halal logistics in Malaysia (Ab Talib et al., 2020; Mahidin et al., 2017; Mohamad et al., 2016; Zailani et al., 2017). Concerning logistics and SMEs, Husny et al. (2016) examine factors that influence Malaysian SMEs' intention to adopt halal logistics services. Arsić et al. (2020) measure the impact of logistics capacity on SMEs' economic sustainability, while Mahidin et al., (2016) investigates the halal logistics issues.

\section{Methods}

Interview sessions (approximately 2 hours) with 10 SMEs' owners were conducted using an online web conferencing application, Cisco Webex. SMEs were chosen because they constitute 99.2 percent of the manufacturing establishments and the growth engine for the Malaysian economy.

Table 1. Respondents Profile

\begin{tabular}{cccc}
\hline Participants & Gender & Years of experience in the industry & Years of the SME's establishment \\
\hline 1 & Male & 7 & 2010 \\
2 & Female & 8 & 2008 \\
3 & Female & 3 & 2017 \\
4 & Male & 3 & 2006 \\
5 & Female & 2 & 2019 \\
6 & Male & 15 & 2000 \\
7 & Male & 9 & 2009 \\
8 & Male & 2 & 2018 \\
9 & Male & 9 & 2005 \\
10 & Female & 10 & 2005 \\
\hline
\end{tabular}

Source: Primary Data, 2021

Before the formal interviews were carried out, the interview questions, adapted from (Mohezar et al., 2017), were piloted with senior managers of a fast-food chain in Malaysia. The questions were then appropriately refined and revised to ensure clarity of the matters to be raised during the interviews. In addition, to ensure the validity and reliability of the information gathered 
from the interviews and reduce the risk of response bias, the answers recorded for each session were re-confirmed at the end of the interview. The business owners were randomly contacted through email. Before conducting the interview session, respondents were informed that their participation is anonymous and voluntary, and their responses are solely be used for this research. The interviews were conducted from May until July 2020. The interviewees' details are listed in Table 1.

\section{Data Analysis}

Content analysis was applied. The analysis consists of two steps. In the first step, the author identifies the groupings and sub-groupings of the SWOT of the F\&B industry. SWOT analysis is a well-known strategic approach mainly used to determine the internal factors (strengths and weaknesses) as well as external factors (opportunities and threats) of a situation (Büyüközkan et al., 2021). Using SWOT analysis, the current situation faced by the industry can be determined and how the future state of the current situation will be predicted. In the second step, the author analyzes the key challenges faced by SMEs in the F\&B industry regarding halal logistics.

\section{Results}

\section{Strengths and Weaknesses}

Most respondents stated that the Malaysian F\&B industry's strength lies in its workforce diversity and well-established equipment and facilities. Respondents 2 and 7 express their thoughts. The following are their feedbacks.

Respondent 2 Interestingly, this F\&B industry comprises a workforce from different social, cultural, and regional backgrounds.

Respondent 7 Like our country's population, the workforce's diversity is significant, enhancing innovation and creativity.

Well-established equipment and facilities also have been highlighted as the strength of the Malaysian F\&B industry as mentioned by one of the respondent.

Respondent 4 Access to proper tools, equipment, and facilities is one of the strengths of this industry. You can either buy or rent it.

Most of the respondents mentioned that a limited number of skilled workforce, lack of industrial collaboration, and lack of distribution channel are among factors that hinder the industry's business growth. The following are their feedbacks.

Respondent 1 Getting enough labor, both unskilled and skilled, is a major concern. This industry requires highly qualified, multi-skilled labor.

Respondent 5 Industrial collaboration is lacking, making it difficult for the small and newly established companies to grow.

Respondent 6 Collaborative research should be enhanced to increase orientationrelated barriers and improve greater trust levels within organizations.

Respondent I think the distribution systems are complex, making it difficult to 10 reach the end customer.

Based on the above, two of the Malaysian F\&B industry's strengths lie in its workforce diversity and well-established equipment and facilities. However, the respondents also mentioned a limited number of skilled workforce, lack of industrial collaboration, and lack of distribution channels in the industry. A similar issue has been raised by various works literature, including (Zailani et al., 2017) and (Ab Talib \& Hamid, 2014). 


\section{Opportunities and Threats}

The increase in demand, advanced technology, supportive government initiatives, and favorable business environment have been pointed to as the industry's opportunities. The respondents mentioned the following.

Respondent 2 Demand for food is continuously increasing, no matter what, making more immense opportunities for doing business in this industry.

Respondents 5, 7, and 10 mentioned the following.

Respondent 5 Advanced technology is needed and widely available for driving future competitiveness. [...] and it's accompanied with cost.

Respondent 7 Even during the most challenging times, the government has provided various initiatives to support this industry.

Respondent Given this country's political and economic condition, F\&B will always 10 offer a positive and healthy environment.

High cost has been identified as one of the threats. The following is the respond of Respondent 4.

Respondent 4 Rising costs for raw materials are burdensome. Should this continues, our profitability will be affected.

Respondent 8 , on the other hand, stressed out that new and changing regulations threaten the industry.

Respondent 8 Many laws and regulations have been amended recently, making it difficult for us to adapt and change. For example, the government recently changes the tax rate. In addition, the Malaysia Food Safety and Quality Division have amended requirements for food labeling, which affected the business.

The interviewee pointed out that an increase in demand, advanced technology, supportive government initiatives, and a favorable business environment is the industry's opportunities. At the same time, high cost and new and changing regulations are highlighted as threats for the industry. Table 2 summarises the content analysis based on the interviews.

Table 2. Content Analysis

\begin{tabular}{|c|c|c|c|c|c|c|c|c|c|c|c|c|}
\hline \multirow{2}{*}{ Variables } & \multirow{2}{*}{ Description } & \multicolumn{10}{|c|}{ Respondent } & \multirow{2}{*}{ Total } \\
\hline & & 1 & 2 & 3 & 4 & 5 & 6 & 7 & 8 & 9 & 10 & \\
\hline \multirow[t]{2}{*}{ Strengths } & Workforce diversity & & $\sqrt{ }$ & $\sqrt{ }$ & $\sqrt{ }$ & $\sqrt{ }$ & & $\sqrt{ }$ & & $\sqrt{ }$ & $\sqrt{ }$ & 7 \\
\hline & $\begin{array}{l}\text { Well established equipments } \\
\text { and facilities }\end{array}$ & $\sqrt{ }$ & $\sqrt{ }$ & & $\sqrt{ }$ & & $\sqrt{ }$ & $\sqrt{ }$ & $\sqrt{ }$ & & & 6 \\
\hline \multirow[t]{3}{*}{ Weaknesses } & $\begin{array}{l}\text { A limited number of skilled } \\
\text { workforce }\end{array}$ & $\sqrt{ }$ & $\sqrt{ }$ & $\sqrt{ }$ & $\sqrt{ }$ & $\sqrt{ }$ & & & $\sqrt{ }$ & $\sqrt{ }$ & $\sqrt{ }$ & 8 \\
\hline & $\begin{array}{l}\text { Lack of industrial } \\
\text { collaboration }\end{array}$ & $\sqrt{ }$ & & $\sqrt{ }$ & & $\sqrt{ }$ & $\sqrt{ }$ & $\sqrt{ }$ & $\sqrt{ }$ & $\sqrt{ }$ & & 7 \\
\hline & Lack of distribution channel & & $\sqrt{ }$ & $\sqrt{ }$ & $\sqrt{ }$ & & $\sqrt{ }$ & & & & $\sqrt{ }$ & 5 \\
\hline \multirow[t]{4}{*}{ Opportunities } & Increasing demand & & $\sqrt{ }$ & $\sqrt{ }$ & & $\sqrt{ }$ & & $\sqrt{ }$ & $\sqrt{ }$ & $\sqrt{ }$ & & 6 \\
\hline & Advanced technology & $\sqrt{ }$ & & & & $\sqrt{ }$ & $\sqrt{ }$ & & $\sqrt{ }$ & $\sqrt{ }$ & $\sqrt{ }$ & 6 \\
\hline & $\begin{array}{l}\text { Supportive government } \\
\text { initiatives }\end{array}$ & & $\sqrt{ }$ & $\sqrt{ }$ & $\sqrt{ }$ & & & $\sqrt{ }$ & $\sqrt{ }$ & & & 5 \\
\hline & $\begin{array}{l}\text { Favourable business } \\
\text { environment }\end{array}$ & $\sqrt{ }$ & $\sqrt{ }$ & & & & & $\sqrt{ }$ & & & $\sqrt{ }$ & 4 \\
\hline \multirow[t]{2}{*}{ Threats } & High cost & $\sqrt{ }$ & $\sqrt{ }$ & & $\sqrt{ }$ & $\sqrt{ }$ & $\sqrt{ }$ & $\sqrt{ }$ & & $\sqrt{ }$ & & 7 \\
\hline & New and changing regulation & & $\sqrt{ }$ & $\sqrt{ }$ & & & & & $\sqrt{ }$ & & $\sqrt{ }$ & 4 \\
\hline
\end{tabular}

Source: Primary Data, 2021 


\section{Demand and Key Challenges}

Regarding demand towards halal food logistics, most of the respondents (8 out of 10 respondents) mentioned that they need halal food logistics to expand their business further worldwide with the rising Muslim consumer demands. They further highlight that they face several challenges concerning logistics issues. Some of the common causes are poor shariah-compliance storage and warehousing practices, delays in transportation, poor communication between food supply chain partners, and lack of international halal certification. The same issues have been highlighted by several authors such as Zailani et al. (2017), Mahidin et al. (2017), and Ab Talib et al. (2013). For example, Ab Talib et al. (2013) mentioned that although Malaysia has provided a direction in ensuring that halal integrity is not compromised along the halal chain, the number of halal-certified third-party LSPs is still scarce. Zailani et al. (2017), on the other hand, mentioned that there's a limited collaboration among LSPs, Halal Industry Development Corporation, and Jabatan Kemajuan Islam Malaysia (JAKIM) in the country affecting the quality and safety of food products. Mahidin et al. (2017) pointed out that there is potential mixing storage of halal and non-halal food in the warehouse, causing halal integrity of the supply chain.

\section{Discussion and Conclusion}

This paper investigates the competitiveness of the $F \& B$ industry in Malaysia and examines the SMEs' demand and key perceptions towards challenges in halal logistics. Interview sessions were conducted with 10 SMEs' owners, and a SWOT analysis was developed for the industry. It was found that there's a vast potential for the Malaysian F\&B sector to grow and move forward, locally and globally. SMEs also received various government support, ranging from financial to business development (Noh \& Saari, 2013). Thus, the opportunities for this industry to enhanced are bigger. Based on the interview sessions, Malaysian SMEs in the F\&B industry are very keen to market their products, thus needing halal logistics to guarantee the halal integrity of food products. However, the literature and the interview session confirmed several challenges concerning logistics issues that restrain the SMEs' development, making halal logistics services less favorable. The challenges include poor shariah-compliance storage and warehousing practices, delays in transportation, poor communication between food supply chain partners, and lack of international halal certification.

The success of the Halal industry mainly relies on logistics service management capabilities in ensuring the integrity of Halal products. Thus, a comprehensive strategy should be planned. The government plays a big role in enhancing the logistic industry. The role of government can be separated into the following six main categories, which is regulation, financial incentives, taxation, infrastructure, guidance and encouragement, and education and labor supply (Ab Talib et al., 2020). The regulations for obtaining halal certification in the country should be made compulsory, and the enforcement to combat the misuse of the Halal logo, such as failure to the separation of halal and non-halal products during the logistics chains, should be eliminated. Financial incentives and tax incentives should broaden up to the logistic operators to further promote the halal industry and halal supply chain. Halal logistics infrastructure would require halal transport carriers, dedicated warehouses and storage units, and ports and terminals. The halal and non-halal products should be separated from each other. In addition to that, more guidance, encouragement, and education are also needed, especially for the early adopters of halal logistics to face challenges such as ambiguous halal guidelines and procedures.

\section{Acknowledgement}

This work was supported by the Ministry of Higher Education Fundamental Research Grant Scheme (FRGS) No R.K130000.7855.5F121. 


\section{References}

Abdullah, S., \& Oseni, U.A (2017). Towards a shari'ah compliant equity-based crowdfunding for the halal industry in Malaysia. International Journal of Business and Society, 18, 223-240. Retrieved from http://www.ijbs.unimas.my/images/repository/pdf/Vol18-S1paper14.pdf

Ab Talib, M. S., \& Hamid, A. B. A. (2014). Halal logistics in Malaysia: A SWOT analysis. Journal of Islamic Marketing, 5(3), 322-343. https://doi.org/10.1108/JIMA-03-2013-0018

Ab Talib, M. S., Pang, L. L., \& Ngah, A. H. (2020). The role of government in promoting Halal logistics: a systematic literature review. Journal of Islamic Marketing. https://doi.org/10.1108/JIMA-05-2020-0124

Ab Talib, M. S., Rubin, L., \& Zhengyi, V. K. (2013). Qualitative research on critical issues in halal logistics. Journal of Emerging Economies and Islamic Research, 1(2), 131-130. https://doi.org/10.24191/jeeir.v1i2.9125

Arsić, M., Jovanović, Z., Tomić, R., Tomović, N., Arsić, S., \& Bodolo, I. (2020). Impact of logistics capacity on economic sustainability of SMEs. Sustainability (Switzerland), 12(5), 1-30. https://doi.org/10.3390/su12051911

Azam, M. S. E., \& Abdullah, M. A. (2020). Global halal industry: Realities and opportunities. International Journal of Islamic Business Ethics, 5(1), 47-59. https://doi.org/10.30659/ijibe.5.1.47-59

Azhar, K. (2019). SMEs need more capacity to boost halal exports. The Edge Malaysia. Retrieved from https://www.theedgemarkets.com/article/smes-need-more-capacity-boost-halalexports

Battour, M., Hakimian, F., Ismail, M., \& Boğan, E. (2018). The perception of non-Muslim tourists towards halal tourism: Evidence from Turkey and Malaysia. Journal of Islamic Marketing, 9(4), 823-840. https://doi.org/10.1108/JIMA-07-2017-0072

Billah, M. M. (2019). Halal Cryptocurrency Management. Palgrave Macmillan.

Büyüközkan, G., Mukul, E., \& Kongar, E. (2021). Health tourism strategy selection via SWOT analysis and integrated hesitant fuzzy linguistic AHP-MABAC approach. Socio-Economic Planning Sciences, 74, 1-14. https://doi.org/10.1016/j.seps.2020.100929

Commission, E. (2006). Competitiveness of the european food industry an economic and legal assessment. Agribusiness, 24(4), 417-439. Retrieved from http://scholar.google.com/scholar?hl=en\&btnG=Search\&q=intitle:Competitiveness + of + the + European + Food+Industry + An + economic + and + legal + assessment $\# 0$

Divianjella, M., Muslichah, I., \& Ariff, Z. H. A. (2020). Do religiosity and knowledge affect the attitude and intention to use halal cosmetic products? Evidence from Indonesia. Asian Journal of Islamic Management (AJIM), 2(2), 71-81. https://doi.org/10.20885/ajim.vol2.iss2.art1

European Commission. (2018). The Food and Beverage Market Entry Handbook: Malaysia. https://doi.org/10.2818/757014

Fischer, C., \& Schornberg, S. (2007). The competitiveness situation of the EU meat processing and beverage manufacturing sectors. Food Economics - Acta Agriculturae Scandinavica, Section C, 4(3), 148-158. https://doi.org/10.1080/16507540701597139

Flanders Investment \& Trade. (2020). Food and Beverages Industry Report (Malaysia 2020). Retrieved from http://www.gtai.de/GTAI/Navigation/EN/Invest/Industries/Consumerindustries/food-beverages.html 
Hassan, S. H., Yee, L. W., \& Ray, K. J. (2015). Purchasing Intention Towards Organic Food Among Generation Y in Malaysia. Journal of Agribusiness Marketing, 7, 16-32. Retrieved from http://www.fama.gov.my/documents/10157/c12a2988-c304-4f1b-ba2f-8fea87a310d9

Husny, Z. J. b. I., Hussein, Z. S. b. M \& Tan, M. I. b. I. (2016). Factors that influence the intention to adopt halal logistics services among Malaysian SMEs: Formation of hypotheses and research model. Asian Social Science, 12(7), 151-158. https://doi.org/10.5539/ass.v12n7p151

Tan, M.I.I., Razali, R. N., \& Husny, Z. J. (2012). The adoption of halal transportations technologies for halal logistics service providers in Malaysia. International Journal of Mechanical, Aerospace, Industrial, Mechatronic and Manufacturing Engineering, 6(3), 10-17.

Italian Trade Agency. (2017). Food and Beverages Market Report in Malaysia.

Jumady, E., Brasit, N., Jusni, J., \& Pono, M. (2016). The effects of integrative supply chain management on the just in time and competitiveness of the food and beverage manufacturing companies in Makassar. Scientific Research Journal, IV(April 2016), 25. Retrieved from www.scirj.org

Karia, N. (2019). Halal logistics: practices, integration and performance of logistics service providers. Journal of Islamic Marketing. https://doi.org/10.1108/JIMA-08-2018-0132

LNG. (2019). Malaysia Food and Beverages Market, Size, Share, Outlook and Growth Opportunities 20202026. Retrieved from https://www.researchandmarkets.com/reports/4854610/malaysiafood-and-beverages-market-size-share

Mahidin, N., Saifudin, A. M., \& Othman, S. N. (2016). A preliminary study of halal logistics issues among food manufacturing companies. Journal of Technology and Operations Management, 11(1), 18-25. https://doi.org/10.32890/jtom2016.11.1.2

Mahidin, N., Saifudin, A. M., \& Othman, S. N. (2017). Halal food logistics: The challenges among food \& beverages small and medium sizes manufacturers. International Journal of Supply Chain $\begin{array}{llll}\text { Management, } & 6(3), & 337-346 . & \text { Retrieved }\end{array}$ https://ojs.excelingtech.co.uk/index.php/IJSCM/article/view/1890/948

Malaysian Investment Development Authority. (2019). Ideal Prospects, Immense Opportunities Diverse Resources. Malaysian Investment Development Authority (MIDA). Retrieved from http://www.mida.gov.my/home/administrator/system_files/modules/photo/uploads/2 0180903103354_Food Industry 2018_V4.pdf

Matulidi, N., Jaafar, H. S., \& Bakar, A. N. (2016). Halal governance in Malaysia companies. Journal of Fatwa Management and Research, 6(2), 73-89. https://doi.org/10.33102/jfatwa.vol20no1.3

Mohezar, S., Moghavvemi, S., \& Zailani, S. (2017). Malaysian Islamic medical tourism market: a SWOT analysis. Journal of Islamic Marketing, 8(3), 444-460. https://doi.org/10.1108/JIMA04-2015-0027

More, A. (2021, April 20). Global halal food market 2021-2025 with top countries data industry growth analysis, segmentation, size, share, trend, future demand and leading players updates by forecast. Retrieved from https://www.thecowboychannel.com/story/43704406/global-halal-food

Noh, F. M. A. K. M., \& Saari, M. Y. (2013). Small and medium food enterprises in Malaysia: Institutional support and policy perspectives. Millennial Asia, 4(2), 185-210. https://doi.org/10.1177/0976399613506317

Notta, O., \& Vlachei, A. (2010). Competitiveness and advertising in greek food and beverage manufacturing firms. Marketing and Management Sciences, 140-146. 
https://doi.org/10.1142/9781848165106_0026

Quoquab, F., Mohamed Sadom, N. Z., \& Mohammad, J. (2019). Driving customer loyalty in the Malaysian fast food industry: The role of halal logo, trust and perceived reputation. Journal of Islamic Marketing, 11(6), 1367-1387. https://doi.org/10.1108/JIMA-01-2019-0010

Rahman, M., Moghavvemi, S., Thirumoorthi, T., \& Rahman, M. K. (2020). The impact of tourists' perceptions on halal tourism destination: A structural model analysis. Tourism Review, 75(3), 575-594. https://doi.org/10.1108/TR-05-2019-0182

Ramli, N., Amin, N., Zawawi, M., \& Aziz, N. A. (2018). Healthcare services: Halal pharmaceutical in Malaysia, issues and challenges. The Malaysian Journal of Consumer and Family Economics, 101-111.

Rezai, G., Mohamed, Z., \& Shamsudin, M. N. (2012). Non-Muslim consumers' understanding of Halal principles in Malaysia. Journal of Islamic Marketing, 3(1), 35-46. https://doi.org/10.1108/17590831211206572

See, S. Z. J., \& Shaheen, M. (2012). Young female motivations for purchase of organic food in Malaysia. International Journal of Contemporary Business Studies, 3(5), 61-72. Retrieved from http://www.akpinsight.webs.com

Suhaimee, S., Abdullah, M. A., \& Alias, S. (2019). Malaysia model: chellenges in halal certification. Halal Journal, 1, 75-92. Retrieved from https://umexpert.um.edu.my/public_view.php?type=publication\&row=OTA2MjU\%3D

Suzana, J. H., Endut, I. R., Faisol, N., \& Omar, E. N. (2011). Innovation in logistics services - halal logistics. In Proceedings of the 16th International Symposium on Logistics (ISL) (pp. 844-855). Berlin.

Toaha, M., Maupa, H., Brasit, N, Taba, I., \& Aswan, A. (2019). Competitive sustainability of food and beverage SMEs in South Sulawesi. Proceeding of the $3^{\text {rd }}$ International Conference on Accounting, Management and Economics, 92, 608-615. https://doi.org/10.2991/icame-18.2019.64

Wajdi, M. F., Aji, H. M., \& Muhammad, S. (2020). Factors affecting the intention to purchase halal cosmetics on Instagram: E-WOM and brand image. Asian Journal of Islamic Management (AJIM), 2(1), 1-11. https://doi.org/10.20885/ajim.vol2.iss1.art1

Wardi, Y., Abror, A., \& Trinanda, O. (2018). Halal tourism: antecedent of tourist's satisfaction and word of mouth (WOM). Asia Pacific Journal of Tourism Research, 23(5), 463-472. https://doi.org/10.1080/10941665.2018.1466816

Wibowo, M. W., \& Ahmad, F. S. (2016). Non-Muslim consumers' halal food product acceptance model. Procedia Economics and Finance, 37(16), 276-283. https://doi.org/10.1016/s22125671(16)30125-3

Zailani, S., Iranmanesh, M., Aziz, A. A., \& Kanapathy, K. (2017). Halal logistics opportunities and challenges. Journal of Islamic Marketing, 8(1), 127-139. https://doi.org/10.1108/JIMA-042015-0028 